\title{
Examining the Map Literacy Levels of Students in the Faculty of Education
}

\author{
Ömer TÜRKSEVER ${ }^{1}$ \\ Yozgat Bozok University, Yozgat, TURKEY
}

1Dr., Yozgat Bozok University, Faculty of Education, Department of Social Studies Education, Erdoğan Akdağ Campus, TURKEY. omer.turksever@bozok.edu.tr. ORCID: 0000-0002-1855-391X

\begin{abstract}
The main aim of this study is to examine the map literacy levels of students who are studying in different departments of a Faculty of Education in response to a range of variables. The research was conducted in a screening model. A map literacy scale was used as the data collection tool in the research. The research was conducted at a university in the Central Anatolia region of Turkey during the academic year 2020-2021. There were 260 participants from six departments of studying the Faculty of Education program (primary, Social Studies, Mathematics, Science, pre-school guidance, and counselling). In solving the problem and sub-problems of the research, $t$-test and one-way analysis of variance techniques was used. As a result of the research, the total map literacy test scores of participating undergraduate students in the Faculty of Education were found to be similar according to gender, class, and variables for the purpose of using the map in daily life. In contrast, from the study, all students in the Faculty of Education who completed the Map Literacy Test, the scores were in favor of those completing Geography courses. For the variable according to the level of participation in various activities in the natural environment, the results were in favor of those completing Social Studies education. Significant differences were found in favor of teacher candidates who were completing the Geography course (branch variable): their interest level was moderate and high. According to research results, in order to improve the level of map literacy amongst undergraduate students in a Faculty of Education, it is recommended to do more activities in Geography courses and to include trip-observation-like applications to increase the frequency of presence in the natural environment.
\end{abstract}

\section{Keywords}

Map Literacy, Map Skills, Map Proficiency Level, Undergraduate Students in a Faculty of Education 
Maps are important tools in teaching Geography. Maps are defined as the essence of Geography and are understood to be one of the most important tools of Geography (Gürsoy, 1961; as cited in Kızılçaoğlu, 2007, p.341).

"The map of human lives or of the area of interest in the whole, or in part, the physical details of these details of cases occurring in this area or details, details, usually on a flat surface, is a representation of a certain scale" ("Harita Genel Komutanlığı").

"Human beings which have economic value in the determination of the distribution area of surface and subsurface resources, the exploitation of these valuable resources development plan for the preparation of the homeland defense and security, in the resolution of border disputes, routes (land, rail, and oil and natural gas pipeline, etc.) in determination, land use studies, etc. in short, he frequently uses maps in many of the works of the place and in the directions of the place" (Koç\&Bulut, 2014, p. 3).

"Maps are widely used in everyday life. Transportation, tourist trips, lectures, scientific studies, direction finding, location and coordinate determination, distance and area calculation, interpretation of physical properties, spatial planning, etc. it is used for many purposes in the subject" (Tümertekin\&Özgüç, 2000).

Drawing, using and interpreting maps is a skillful process. Skill as a word meaning " it is the ability of a person to achieve a job and conclude an action according to the purpose, depending on predisposition and learning" (Türk Dil Kurumu)."To be able to perform any activity continuously at a certain level of competence" (Paykoç, 1991, p.13).

The concept of literacy in the world of education is one of the most prominent concepts of recent times in literature. Literacy standards are set for various subjects or disciplines. "Although the origin of the concept of literacy refers only to their ability to read and write, the scope of use of this concept expanded after the Industrial Revolution. After the Industrial Revolution, this concept is used in the sense of being literacy in a particular field or having a wide knowledge of a particular field" (McBride, 2011:23).

Map literacy allows the individual to understand and interpret thoughts, actions, objects, graphics and symbols. It also helps a person to create learning awareness throughout his or her life. Map literacy is the use of map knowledge and skills. It covers knowledge and skills that require solving spatial problems in individuals ' daily lives. "Individuals, military, and economic life and in their daily lives for various purposes (such as location and direction) of the map skills to make effective and efficient use must be whether literate or advanced if you have a good map. Map literacy will be able to benefit a person on many issues, including time, social and economic" (Koç, Aksoy \&Çifçi, 2017).

Buckley, Muehrcke and Muehrcke (2011), defined map literacy as the ability to use maps and divided this skill into three categories: reading the map; analyzing 
the map; and interpreting the map. Olson (1976)identified three levels of map literacy which become progressively more difficult: to compare individual symbol characteristics; to recognize the characteristics of symbol groups on the map as a whole; and to use maps as a tool for structuring information in decision-making.

"Map literacy is the ability to use maps in everyday life and understand maps. Map literacy consists of knowledge, understanding, application, analysis, synthesis and evaluation steps" (Clarke, 2003, p. 717). Weeden (1997, p. 169) listed his interpretation of map skills as "using maps, making maps, literacy maps and interpreting maps".

Within the framework of the discipline of Social Sciences, there have been many studies related to map literacy, especially in Geography education (Demiralp, 2006; Üzümcü, 2007; Ertuğrul, 2008; Koç, 2008; Sönmez\& Aksoy, 2012; Aksoy, 2013; Yurdam, 2013; Aksoy, Kılıçoğlu\&Ablak, 2015; Abbak, 2016; Kartal, 2016; Kuzey, 2016; Tokcan and Balcı, 2016; Yaylacı\& Aksoy, 2017; Ablak\& Aksoy, 2018; Aksoy \&Ablak, 2019; Aksoy, 2019; Aksoy \&Namal, 2020). In addition, research was conducted in which the map skills of undergraduate students' indifferent branches of a Faculty of Education were determined. In these studies, it was found that the level of map skills of undergraduate students of Geography and Social Studies education was higher than in other branches of education (Duman\&Girgin, 2007; Merç, 2011; Balcı, 2015; Cendek, 2015; Güneş, 2016).

The first course that individuals encounter with map knowledge and skills in their lives is the Social Studies course after life knowledge (Tokcan, 2015). Later in high school, after Grades 1 and 2, geography courses in the classroom include map information topics in parallel with the Social Studies course. Therefore, it is important to determine the level of map literacy of the undergraduate students of the Faculty of Education who are trained in map knowledge and continue their undergraduate education in these courses because teacher candidates will transfer their map literacy skills directly or indirectly to their students.

The main purpose of this research is to examine the map literacy levels of undergraduate students in a Faculty of Education who study in different undergraduate programs in terms of several variables. Many studies have previously been conducted on map literacy; however, these are Geography education teacher candidates, Social Studies teacher candidates, or studies between students in different faculties of the university. The current study is important because it is the first study conducted on students who are studying in different undergraduate programs within a Faculty of Education.

\section{Methodology}

In this study, a screening model was used. "A survey model is a study aimed at collecting data to determine specific characteristics of a group."(Büyüköztürk, Çakmak, Akgül, Karadeniz \&Demirel, 2009). According to Karasar (1999), "survey models are research approaches aimed at describing a situation that existed in the past or still as it existed". 


\section{Working Group}

The research occurs during the academic year of 2020-2021 in the fall semester. The study group are from a university in the central Anatolia region; they are studying across 6 different programs in the Faculty of Education (primary, Social Studies, Mathematics, Science, pre-school guidance, and counselling). There are 260 undergraduate students in the study. The study group consists of $74.5 \%$ female and $25.5 \%$ male undergraduate students.

\section{Data Collection}

In this study, the map literacy scale developed by Koç and Demir (2014) was used to determine the map literacy levels of undergraduate students in the Faculty of Education. This scale has five dimensions, including a 23-point map information test, and a test for the ability to process a map consisting of four items. The kr-20 reliability co-efficient of the map information test consisting of 23 items was 0.76; the Cronbach Alpha multiple of the size of the operation with maps consisting of four items configured in the Likert-scale of five was 0.834 .

\section{Data Analysis}

Statistical analyses were performed using the "SPSS 25 program". A T-test for unrelated samples occurs between map literacy scores of undergraduate students in a Faculty of Education and the independent variables. ANOVA was performed for independent groups. In analyzing the data from this study, the map literacy score was obtained by taking the total score of the four sub-dimensions that make up the map proficiency size together with the total score of the 23 items that make up the map knowledge test; then the analyses were made. The Tukey HSD multiple comparison test was used to reveal differences between groups.

\section{Findings}

\section{Findings on the Difference in Map Literacy Scores of Undergraduate Students of the Faculty of Education by Gender}

A T-test was performed for independent groups to determine whether the map literacy scores of undergraduate students in a Faculty of Education differed by gender. The results of the analysis are given in Table 1.

Table 1

T-Test Results for Differences in Map Literacy Scores of Undergraduate Students in a Faculty of Education by Gender Variable

\begin{tabular}{lllllll}
\hline Gender & $\mathrm{N}$ & $\overline{\mathrm{X}}$ & $\mathrm{S}$ & $\mathrm{df}$ & $\mathrm{t}$ & $\mathrm{p}$ \\
\cline { 1 - 4 } Female & 193 & 84,24 & 19,21 & 258 & 1,729 &, 085 \\
\cline { 1 - 2 } Male & 67 & 79,54 & 19,13 & & &
\end{tabular}

When looking at Table 1, the map literacy scores of undergraduate students in a Faculty of Education did not differ significantly according to the gender variable 
$[\mathrm{t}(258)=1,729 ; \mathrm{p}>05]$. This finding can be interpreted, as the map literacy levels of undergraduates in the Faculty of Education who study in different programs are similar by gender.

\section{Findings on the Difference of Map Literacy Scores of Undergraduate Students in a Faculty of Education According to the Status of Those Taking a Geography Course}

A T-test was performed for independent groups to determine whether the map literacy scores of undergraduate students' in a Faculty of Education differed according to the state of taking a Geography course. The results of the analysis are given in Table 2 .

Table 2

T-Test Results for the Difference of Map Literacy Scores of Undergraduate Students Ina Faculty of Education According To the Geography Course Status Variable

\begin{tabular}{lllllll}
\hline $\begin{array}{l}\text { Getting a } \\
\begin{array}{l}\text { Geography } \\
\text { Lesson Status }\end{array}\end{array}$ & $\mathrm{N}$ & $\overline{\mathrm{X}}$ & $\mathrm{S}$ & $\mathrm{df}$ & $\mathrm{t}$ & $\mathrm{p}$ \\
\cline { 1 - 6 } Yes & 165 & 84,93 & 18,21 & 258 & 4,806 &, 000 \\
\cline { 1 - 4 } & 95 & 73,51 & 18,87 & & & \\
\hline
\end{tabular}

In Table 2, the map literacy scores of undergraduate students in a Faculty of Education differed significantly in favor of candidate teachers who took a Geography course, according to the geography course status variable $[\mathrm{t}(258)=$ 4,806; $\mathrm{p}<05]$. This finding can be interpreted as higher literacy levels amongst those undergraduate students from the Faculty of Education who took Geography courses.

\section{Findings on the Difference of Map Literacy Scores Of Undergraduate Students In Accordance With The Branch Variable}

A one-way variance analysis was performed for independent groups to determine whether the map literacy scores of undergraduate students in a Faculty of Education differed according to the branch variable they studied. The results of the analysis are given in Table 3.

Table 3

One-Way Analysis of Variance (ANOVA) Results for the Difference of Map Literacy Scores Of Undergraduate Students in a Faculty of Education by the Program or Branch Variable

\begin{tabular}{|c|c|c|c|c|c|c|}
\hline $\begin{array}{l}\text { Source of } \\
\text { Variance }\end{array}$ & $\begin{array}{l}\text { Sum of } \\
\text { squares }\end{array}$ & $\mathrm{df}$ & $\begin{array}{l}\text { Mean } \\
\text { squares }\end{array}$ & $\mathrm{F}$ & $\mathrm{p}$ & $\begin{array}{l}\text { Difference } \\
\text { Tukey }\end{array}$ \\
\hline $\begin{array}{l}\text { Between } \\
\text { Groups }\end{array}$ & 11349,503 & 5 & 2269,901 & \multirow[t]{3}{*}{6,834} & \multirow[t]{3}{*}{,000 } & $\begin{array}{l}1-2 \\
2-4\end{array}$ \\
\hline Within Groups & 84364,744 & 254 & 332,145 & & & $2-5$ \\
\hline Total & 95714,246 & 259 & & & & \\
\hline
\end{tabular}


According to the results of the variance analysis in Table 3, the "map literacy" scores of undergraduate students in a Faculty of Education differed significantly according to the program or branch variable $[\mathrm{F}(5-254)=6,834 ; \mathrm{p}<, 05]$. A Tukey HSD multiple comparison test was performed to determine which groups had significant differences. Based on multiple comparison test results, the difference was found to be in favor of undergraduates in Social Studies education ( $X=87.75)$, with primary education $(X=78.62)$, Science education $(X=72.72)$, and Mathematics education $(X=70.13)$ being among those in Social Studies education. This finding shows that the map literacy levels of students in the Faculty of Education completing a Social Studies course are higher than those in the program of primary education, Science education and Mathematics education.

Table 4

Descriptive Data about the Branch Variable

\begin{tabular}{llll}
\hline Branch & N & $\bar{X}$ & $\mathrm{~S}$ \\
\hline Primary Education & 61 & 78,62 & 15,19 \\
\hline Social Studies Education & 102 & 87,75 & 19,54 \\
\hline Preschool Education & 25 & 82,92 & 22,86 \\
\hline Science Education & 18 & 72,72 & 16,71 \\
\hline Mathematics Education & 38 & 70,13 & 15,24 \\
\hline Guidance and psychological counseling & 16 & 75,12 & 20,14 \\
\hline
\end{tabular}

Findings on the Difference of Map Literacy Scores of Undergraduate Students in the Faculty of Education According to the Class Variable

A one-way variance analysis was performed for independent groups to determine whether the map literacy scores of undergraduate students in a Faculty of Education differed according to the class variable. The results of the analysis are given in Table 5.

Table 5

One-Way Analysis of Variance (ANOVA) Results for the Difference of Map Literacy Scores of Undergraduate Students in a Faculty of Education by Class Variable

\begin{tabular}{llllll}
\hline Source Variance & $\begin{array}{l}\text { Sum of } \\
\text { squares }\end{array}$ & $\mathrm{df}$ & $\begin{array}{l}\text { Mean } \\
\text { squares }\end{array}$ & $\mathrm{F}$ & $\mathrm{p}$ \\
\hline $\begin{array}{l}\text { Between } \\
\text { Groups }\end{array}$ & 884,861 & 3 & 294,954 & \multirow{2}{*}{, 796} & ,497 \\
\cline { 1 - 4 } Within Groups & 94829,385 & 256 & 370,427 & & \\
\cline { 1 - 5 } Total & 95714,246 & 259 & & & \\
\cline { 1 - 3 }
\end{tabular}

According to the results of the variance analysis in Table 5,the map literacy scores of undergraduate students in a Faculty of Education did not differ significantly compared to the class level variable $[\mathrm{F}(3-256)=0.796 ; \mathrm{p}>, 05]$. This finding shows that the map literacy levels of undergraduate students in a Faculty of Education who study at different grade levels are similar. 
Table 6

Descriptive Data for a Class-Grade Variable

\begin{tabular}{llll}
\hline Level & $\mathrm{N}$ & $\overline{\mathrm{X}}$ & $\mathrm{S}$ \\
\cline { 2 - 4 } 1. Grade & 134 & 79,97 & 19,55 \\
\hline 2. Grade & 60 & 79,13 & 20,56 \\
\hline 3. Grade & 24 & 83,00 & 15,91 \\
\hline 4. Grade & 42 & 84,29 & 17,97 \\
\hline
\end{tabular}

Findings on the Difference of Map Literacy Scores of Undergraduate Students In Accordance With the Frequency of Using Maps

A one-way variance analysis was performed for independent groups to determine whether the map literacy scores of undergraduate students in a Faculty of Education differed according to the frequency of using the map. The results of the analysis are given in Table 7.

Table 7

One-Way Analysis of Variance (ANOVA) Results for the Difference of Map Literacy Scores of Undergraduate Students of the Faculty of Education In Relation To the Frequency Variable of Use of Maps

\begin{tabular}{|c|c|c|c|c|c|c|}
\hline Source Variance & $\begin{array}{l}\text { Sum of } \\
\text { squares }\end{array}$ & $\mathrm{df}$ & $\begin{array}{l}\text { Mean } \\
\text { squares }\end{array}$ & $\mathrm{F}$ & $\mathrm{p}$ & $\begin{array}{l}\text { Difference } \\
\text { Tukey }\end{array}$ \\
\hline $\begin{array}{l}\text { Between } \\
\text { Groups }\end{array}$ & 22906,198 & 3 & 7635,399 & 26,847 & 000 & $\begin{array}{l}1-2 \\
1-3\end{array}$ \\
\hline Within Groups & 72808,048 & 256 & 284,406 & & & $1-4$ \\
\hline Total & 95714,246 & 259 & & & & $\begin{array}{l}2-3 \\
2-4\end{array}$ \\
\hline
\end{tabular}

According to the results of the variance analysis in Table 7, the map literacy scores of undergraduate students in a Faculty of Education differed significantly according to the frequency of using the map $[\mathrm{F}(5-254)=26,847 ; \mathrm{p}<, 05]$. Tukey's multiple comparison test was performed to find the source of the difference. According to the results of the map, there were significant differences in favor of medium and low users.

Table 8

Descriptive Data on the Frequency Variable Using the Map

\begin{tabular}{llll}
\hline Frequency of using maps & $\mathrm{N}$ & $\overline{\mathrm{X}}$ & $\mathrm{S}$ \\
\cline { 3 - 4 } 1.Never & 27 & 64,07 & 16,76 \\
\hline 2.Slightly & 129 & 75,82 & 16,92 \\
\hline 3.Medium & 91 & 90,09 & 17,54 \\
\hline 4.Many & 13 & 99,00 & 9,98 \\
\hline
\end{tabular}


Türksever, Ö. (2021). Examining the map literacy levels of students in the faculty of education

\section{Findings on the Difference of Map Literacy Scores of Undergraduate Students In Accordance With the Frequency of Participation in Activities in a Natural Environment}

A one-way variance analysis was performed for independent groups to determine whether the map literacy scores of undergraduate students in aFaculty of Education differed according to the frequency of participation in activities in the natural environment. Analysis results are given in Table 9.

Table 9

One-Way Analysis of Variance (ANOVA) Results for the Difference of Map Literacy Scores of Undergraduate Students In Relation To the Frequency Variable of Participation in Activities in the Natural Environment

\begin{tabular}{|c|c|c|c|c|c|c|}
\hline Source Variance & $\begin{array}{l}\text { Sum of } \\
\text { squares }\end{array}$ & $\mathrm{df}$ & $\begin{array}{l}\text { Mean } \\
\text { squares }\end{array}$ & $\mathrm{F}$ & $\mathrm{p}$ & $\begin{array}{l}\text { Difference } \\
\text { Tukey }\end{array}$ \\
\hline $\begin{array}{l}\text { Between } \\
\text { Groups }\end{array}$ & 5488,723 & 3 & 1829,574 & 5,191 & ,002 & $\begin{array}{l}1-2 \\
1-3\end{array}$ \\
\hline Within Groups & 90225,523 & 256 & 352,443 & & & \\
\hline Total & 95714,246 & 259 & & & & \\
\hline
\end{tabular}

According to the results in Table 9, the map literacy scores of undergraduate students in a Faculty of Education differed significantly according to the frequency variable of participation in activities in the natural environment $[F(3-256)=5,191$; $\mathrm{p}<, 05]$. According to the results of multiple comparison tests, this difference was found in favor of undergraduate students who were very small and moderate in the natural environment and those who were not at all. This finding can be interpreted as a positive reflection of the frequency of presence in the natural environment on the map knowledge and skills of undergraduate students in a Faculty of Education.

Table10

Descriptive Data on Activity Participation Frequency Variable

\begin{tabular}{llll}
\hline $\begin{array}{l}\text { Frequency of participating in the } \\
\text { activity }\end{array}$ & $\mathrm{N}$ & $\overline{\mathrm{X}}$ & $\mathrm{S}$ \\
\hline 1.Never & 137 & 76,83 & 19,49 \\
\hline 2.Slightly & 89 & 83,79 & 17,12 \\
\hline 3.Medium & 28 & 90,32 & 19,86 \\
\hline 4.Many & 6 & 80,67 & 20,58 \\
\hline
\end{tabular}

Findings on the Difference of Map Literacy Scores of Undergraduate Students in a Faculty of Education According To the Purpose of Using the Map

A one-way variance analysis was performed for independent groups to determine whether the map literacy scores of undergraduate students in a Faculty of Education differed according to the purpose of using the map. The results of the analysis are given in Table 11. 
Table 11

One-Way Analysis of Variance (ANOVA) Results for the Difference of Map Literacy Scores of Undergraduate Students in a Faculty of Education In Relation to the Variable of the Purpose of Using the Map

\begin{tabular}{|c|c|c|c|c|c|}
\hline Source Variance & $\begin{array}{l}\text { Sum of } \\
\text { squares }\end{array}$ & $\mathrm{df}$ & $\begin{array}{l}\text { Mean } \\
\text { squares }\end{array}$ & $\mathrm{F}$ & $\mathrm{P}$ \\
\hline $\begin{array}{l}\text { Between } \\
\text { Groups }\end{array}$ & 2163,045 & 3 & 721,015 & 1,973 & ,118 \\
\hline Within Groups & 93551,201 & 256 & 365,434 & & \\
\hline Total & 95714,246 & 259 & & & \\
\hline
\end{tabular}

According to the findings in Table 11, the map literacy scores of undergraduate students in a Faculty of Education did not differ significantly according to the purpose variable for using the map $[\mathrm{F}(3-256)=1,973 ; \mathrm{p}>, 05]$.

Table 12

Descriptive Data for the Purpose Variable to Use a Map

\begin{tabular}{llll}
\hline Purpose of using maps & $\mathrm{N}$ & $\overline{\mathrm{X}}$ & $\mathrm{S}$ \\
\hline 1.Tourist travels & 14 & 75,43 & 18,29 \\
\hline 2.Location and direction & 129 & 80,81 & 18,92 \\
\hline 3.Academic work & 4 & 101,75 & 8,58 \\
\hline 4.While studying & 113 & 80,61 & 19,63 \\
\hline
\end{tabular}

Findings on the Difference of Map Literacy Scores of Undergraduate Students in a Faculty of Education According to Their Level of Interest in Geography

A one-way variance analysis was performed to determine whether the map literacy scores of undergraduate students in a Faculty of Education differed according to the level of interest in Geography. The results of the analysis are given in Table 13.

Table 13

One-Way Analysis of Variance (ANOVA) Results for the Difference of Map Literacy Scores of Undergraduate Students in a Faculty of Education According To the Level of Interest in Geography Variable

\begin{tabular}{|c|c|c|c|c|c|c|}
\hline Source Variance & $\begin{array}{l}\text { Sum of } \\
\text { squares }\end{array}$ & df & $\begin{array}{l}\text { Mean } \\
\text { squares }\end{array}$ & $\mathrm{F}$ & $\mathrm{p}$ & $\begin{array}{l}\text { Difference } \\
\text { Tukey }\end{array}$ \\
\hline Between & 13577,680 & 3 & 4525,893 & 14,106 & 000 & $1-3$ \\
\hline Groups & & & & & & $1-4$ \\
\hline Within Groups & 82136,566 & 256 & 320,846 & & & $2-3$ \\
\hline Total & 95714,246 & 259 & & & & $2-4$ \\
\hline
\end{tabular}

According to the results in Table 13, a significant difference was found in the map literacy scores of undergraduate students in a Faculty of Education compared to the level of interest in Geography variable. [F $(3-256)=14,106 ; \mathrm{p}<, 05]$. According to the results of the Tukey multiple comparison test conducted to determine the source of the difference, significant differences were found between students who had a lot of and moderate interest in Geography compared with 
students who had no interest and little interest in Geography. The results were in favor of students who had a lot of and moderate interest in Geography. This finding can be interpreted as better map literacy levels of students with high levels of interest in Geography.

Table14

Descriptive Data on the Variable of Interest in Geography

\begin{tabular}{llll}
\hline Interest in geography & $\mathrm{N}$ & $\overline{\mathrm{X}}$ & $\mathrm{S}$ \\
\hline 1.Never & 23 & 62,65 & 15,20 \\
\hline 2.Slightly & 21 & 68,33 & 16,97 \\
\hline 3.Medium & 136 & 82,53 & 16,75 \\
\hline 4.Many & 80 & 86,20 & 20,57 \\
\hline
\end{tabular}

Result and Discussion

The map literacy scores of undergraduate students in a Faculty of Education did not differ significantly by gender variable. A similar conclusion based on the gender variable was reached in a study by Koç and Önal (2016) about geography teacher candidates. In contrast, studies by Koç and Karatekin (2015), Koç and Çifçi (2016) and Koç, Aksoy and Çifçi (2017) determined that according to the gender variable, male undergraduate students in a Faculty of Education had higher literacy levels than female teacher candidates, meaning there was a significant difference in favor of male teacher candidates. Kartal (2016) found no significant differences between the levels of literacy of secondary school students by gender. In a study by Aksoy and Ünlü (2012), they found "the attitude about Geography of Secondary School students differs significantly in favor of female students". Artvinli (2010) found "no significant gender difference between High School students ' attitudes towards Geographic Information Systems".

Map literacy scores of undergraduate students in a Faculty of Education differed significantly in favor of candidate teachers who took a Geography course, according to the Geography course status variable. Again, according to research results, the map literacy scores of undergraduate students in a Faculty of Education differed significantly in favor of those completing Social Studies education according to the program or branch variable. Koç and Karatekin (2015), Koç and Çifçi (2016), Koç and Önal (2016), Kartal and Koç (2017) confirm this result with their work. Map literacy levels of all students in the Faculty of Education for Social Studies education are more in favor than those teacher candidates in Science education and Mathematics education programs.

Map literacy scores of undergraduate students in a Faculty of Education were found to be similar according to the class level variable and no significant difference was found. In the research conducted by Ablak and Aksoy (2016) on the examination of the map literacy of undergraduate students of social studies 
education faculty, " 3 . The map literacy level of the 4 th and 4 th grade students was found to be higher than the 1 st and 2 nd grade students.

Map literacy scores of undergraduate students in a Faculty of Education showed a significant difference in map usage frequency. According to the results of the Tukey multiple comparison test, significant differences were found between those who used the map at a medium and very small level compared to those who did not use it at all. The results were in favor of those who used it at a very, medium and very small level. This result is similar to the research results of Koç and Karatekin (2016), Kartal and Koç (2017), Koç and Çifçi (2016) and Koç and Önal (2016), Aksoy and Ablak (2019), Koç, Aksoy and Çifçi (2017). In these studies, map literacy levels of students or undergraduate students in a Faculty of Education increase according to the frequency of map use. Çavuş (2019) concluded that "the acquisition of directional knowledge increases map literacy skills".

The map literacy scores of the undergraduate students in a Faculty of Education differed significantly according to the frequency variable of participation in activities in the natural environment. According to the results of the Tukey multiple comparison test, this difference was found in favor of teacher candidates who were at a very small and moderate level compared to students who were at a very small and moderate level in the natural environment, and compared to those who were not at all. This finding can be interpreted as a positive reflection of the frequency of presence in the natural environment on the map knowledge and skills of undergraduate students in a Faculty of Education. This result is similar to the work of Koç, Aksoy and Çifçi (2017). In this study, it is seen that among students studying in different undergraduate departments and who participate in activities in the natural environment, have significantly higher map literacy than those who do not participate in such activities. In contrast, the results of the research for this finding differ from the results of the studies conducted by Koç and Karatekin (2016), Koç and Çifçi (2016), Koç and Önal (2016) and Kartal and Koç (2017).

Map literacy scores of undergraduate students in a Faculty of Education did not differ significantly according to the purpose variable for using the map. This result is similar to the work of Kartal and Koç (2017), Koç and Çifçi (2016) and Koç and Önal (2016). This result differs from the work of Koç, Aksoy and Çiftçi (2017). In this study, a significant difference was found between undergraduate students who used the map on tourist trips and those who used it while studying. The results were in favor of undergraduate students who used it while studying.

According to the results of the research, significant differences were found between students who had a lot of and moderate interest in Geography compared to those who had no interest and little interest in Geography. The results were in favor of students who had a lot of and moderate interest. This finding can be interpreted as better map literacy levels amongst students with high levels of interest in Geography. A similar conclusion was reached in studies conducted by Koç and Karatekin (2016), Koç and Çifçi (2016), Koç and Önal (2016), Kartal, Koç 
(2017) and Koç, Aksoy and Çifçi (2017). Aksoy and Ünlü (2012) found that "the use of maps has a positive effect on improving the perception skills of secondary students."

\section{Suggestions}

- This study was conducted only on teacher candidates who were studying in different branches in a Faculty of Education of a university located in the Central Anatolia region of Turkey. The study group can be extended to different educational faculties in Turkey and can be conducted on a wider sample group.

- This study is limited to undergraduate students studying in a Faculty of Education. A comparative study can be conducted on the level of map literacy of undergraduate students studying at different faculties.

- This study was conducted to detect a condition related to a particular type of survey. Studies based on qualitative analysis can be done to learn more deeply about the factors affecting the map literacy levels of undergraduate students.

- According to the results of the study, as the frequency of map use amongst undergraduate students in a Faculty of Education, the level of map literacy also increases. For this reason, in order to increase the level of map literacy amongst undergraduate students in a Faculty of Education, activities should be carried out for applying as many maps as possible in the Geography courses they are studying.

- According to the results obtained, map literacy levels increase as the frequency of undergraduate students investigating the natural environment increases. For this reason, it may be recommended that Faculties take Geography field0-trips at least once a year in Geography courses because participate in such activities will improve the map literacy skills of those students.

\section{References}

Abbak, A. C. (2016). Examining map reading and interpretation skills of social studies lesson according to the opinions of teachers and students. Unpublished Master Thesis. Çukurova University Institute of Social Sciences, Adana.

Ablak, S., \& Aksoy, B. (2018). Examination of student perceptions about the ability to perceive space in social studies curriculum. Turkish Studies International Periodical for the Languages, Literature and History of Turkish or Turkic 13 (11), 1-32.

Aksoy, B. (2013). Investigation of map pingskills of pre-service teachers as regards to various parameters. Educational Researchand Reviews, 8(4), 134-143.

Aksoy, H. (2012). The effects of practices aimed at providing map skills in geography lessons on the attitudes of teachers and students. Unpublished Master Thesis. Marmara University Institute of Educational Sciences, Istanbul

Aksoy. B. (2019). Determination of map literacy of undergraduate geography students, Review of International Geographical Education Online, 9(3), 591-603.

Aksoy, B. \& Ablak, S. (2019). An Evaluation of map literacy of social studies preservice teachers. Participatory Educational Research (PER) Vol. 6(2), pp. 158-168. 
Aksoy, H., \& Ünlü, M. (2012). Effects of mapping skills in geography lessons on student attitudes. Marmara geography magazine, 26, 16-41.

Aksoy, B. ve Namal, R. (2020). Scope Validity of the Graph Drawing and Interpretation Skill Checklist, International Education Studies, 13(1) 76-83.

Aksoy, B., Kılıçoğlu, G. \& Ablak, S. (2015): The relationship between map skill levels and mathematics achievements of students in the 11-14 age group. Journal of World of Turks, 7 (2), 59-71.

Artvinli, E. (2010). Contribution of Geographical Information Systems (GIS) to geography teaching and secondary school students' attitudes towards GIS. Educational Sciences: Theory \& Practice, 10 (3), 1255-1292.

Balcl, A. (2015). A research to determine the map literacy of undergraduate students of the faculty of geography education in geographical land applications. Journal of Academic Social Research, (10), 16-35.

Büyüköztürk, Ş., Çakmak, K. E., Akgül, E. Ö., Karadeniz, Ş. \& Demirel, F. (2009). Bilimsel Araştırma Yöntemleri. Ankara: Pegem Akademi.

Buckley, A. R.,Muehrcke, P. C. \&Muehrcke, J. O. (2011). Map Use: Reading, Analysis and Interpretation. Redlands, CA: Esri Press.

Cendek, M. E. (2015). Social studies teachers' views on the development of "map literacy" in students. Master Thesis, Marmara University Institute of Educational Sciences, Istanbul.

Clarke, D. (2003). Are you functionally map literate?, Proceedings of the 21st International Cartographic Conference (ICC). South Africa: Durban. 10-16 August, 713-719.

Çavuş, E.I. (2019). Developing "map literacy" skills of special education students in social studies lesson. Unpublished Master Thesis. Gazi University Institute of Educational Sciences, Ankara.

Çetin, T., Karakuş, U. \& Üzümcü, N.O. (2008). Acquiring map-reading skill with active learning method in social studies course. International Symposium on Social Sciences Education (14-16 May 2008) Proceedings Book (Ed. Assoc. Çanakkale 18 Mart University Publications No: 922, Çanakkale.

Demiralp, N. (2006). Map and globe use skills in geography education. Turkish Journal of Educational Sciences, 4 (3), 323-343.

Duman, B., \& Girgin, M. (2007). Education faculty students' views on "map literacy". Eastern Geographical Review, 12 (17), 185-202.

Ertuğrul, Z. (2008). Determination of map and globe usage skills of primary school 6th grade students. Unpublished Master Thesis. Gazi University Institute of Educational Sciences, Ankara.

Güneş, G. (2016). The ability of undergraduate students of social studies education faculty to use map and map symbols in geography subjects. Unpublished Master Thesis. Ahi Evran University Institute of Social Sciences, Kırşehir.

Harita Genel Komutanlığı. Retrieved from https://www.harita.gov.tr/images/egitim/ 87245f4b1d0d12c.pdf

Jongwon, L. \& Bednarz R. (2012). Components of spatial thinking: evidence from a spatial thinking ability test. Journal of Geography, 111(1), 15-26.

Karasar, N. (1999). Bilimsel Araştırma Yöntemi. Ankara: Nobel Yayınları. 
Kartal, F. (2016). Examination of map literacy levels of secondary school students in terms of various variables, Cumhuriyet University Institute of Educational Sciences, Unpublished Master's Thesis, Sivas.

Kartal, F. and Koç, H. (2017), Examination of Map Literacy Levels of Secondary Education (9th Grade) Students in Terms of Various Variables, Journal of Eastern Geography, 22, (37), 179-198.

Kızılçaoğlu, A. (2007). A pedagogical look at map skills. Selçuk University Journal of Social Sciences Institute, (18), 341-358.

Koç, H. (2008). The effect of the acquisitions in the geography curriculum on students' map skill levels. Unpublished Doctorate Thesis, Gazi University, Institute of Educational Sciences, Ankara.

Koç H. \& Demir S. B. (2014). Developing valid and reliable map literacy scale. Review of International Geographical Education, 4(2), 120-136.

Koç H. and Bulut İ. (2014). A study to determine the effect of Gestalt theory on students' map reading and interpretation skills, Marmara Geography Journal, 30 (1), 1-19.

Koç, H., \& Karatekin K. (2015). Examination of map literacy levels of social studies teacher candidates in terms of various variables. IV. International Social Studies Education Symposium. (23-25 April 2015), Bolu.

Koç, H., \& Çifçi T. (2016). Examination of Map Literacy Levels of Classroom Teacher Candidates in Terms of Various Variables, Marmara Geography Journal, 34, 9-20.

Koç, H. and Önal, H. (2016). Investigating Geography Teacher Candidates' Map Literacy Levels in Terms of Different Variables, In Recep EFE Irina KOLEVA, Emin ATASOY, İsa CÜREBAL (Eds.), Developments in Educational Sciences, Chapter 59, 727-744, ST. Kliment Ohridski University Press, Sofia

Koç, H., Aksoy, B. \& Çifçi, T. (2017). Examination of map literacy levels of students in different undergraduate programs in terms of various variables: Cumhuriyet University example. Erzincan University Journal of Education Faculty, 19 (3), 301321.

Kuzey, M. (2016). A review of secondary school students' map and direction literacy. Unpublished Doctoral Thesis. Atatürk University Institute of Educational Sciences, Erzurum.

Mcbride, B. (2011). Essential elements of ecological literacy and the pathways to achieve it: perspectives of ecologists. Unpublished Doctoral Dissertation, The University of Montana, Missoula.

Merç, A. (2011). Spatial cognition and map reading skills of social studies and preschool students. Unpublished master's thesis. Adnan Menderes University Institute of Social Sciences, Aydın.

Olson, J. M. (1976). A coordinated approach to map communication improvement. The American Cartographer, 3(2), 151-159.

Paykoç, F. (1991). Tarih Öğretimi. Eskişehir: Anadolu Üniversitesi Açık öğretim Yayınları.

Sönmez, Ö. F., \& Aksoy, B. (2012). Determination of map skill levels of primary school second grade students. Turkish Studies, 7 (1), 1905-1924.

Tokcan, H. (2015). Sosyal Bilgilerde Kavram Öğretimi. Ankara: Pegem Akademi

Tokcan, H., \& Balcl, M. (2016). The Levels of Education Faculty Undergraduate Students Determining the States of the Turkic World on the Map. International Symposium on 
Education and Social Sciences in Turkish Cultural Geography, Gaziantep University Nizip Faculty of Education, Nizip, 5-7 May 2016. (E book e-ISBN: 978-605-318-6557)

Tümertekin, E. ve Özgüç, N. (2000). Coğrafya, Geçmiş Kavramlar Coğrafyacılar. İstanbul: Çantay Kitabevi

Türk Dil Kurumu (n.d.). Retrieved from http://tdk.gov.tr

Üzümcü, O. N. (2007). Teaching map reading skill through active learning method in primary school 6th grade social studies lesson. Unpublished Master Thesis. Gazi University Institute of Educational Sciences, Ankara.

Weeden, P. (1997). Learning through maps. In D. Tilbury \& M. Williams (Eds.), Teaching and learning geography, (pp. 168-179). London: Routledge.

Yaylacı, Z., \& Aksoy, B. (2017). Directing students with intellectual disabilities Acquisition of skill. Anatolian Journal of Cultural Studies, 1 (1), 35-50.

Yurdam, A. H. (2013). GIS for process-based geography lessons: an action research based on student interactions. Unpublished Master Thesis. Ege University Institute of Social Sciences, İzmir.

\section{Biographical Statement}

Ömer TÜRKSEVER works at the Department of Turkish and Social Sciences at Yozgat Bozok University. He has studies in geography education and social studies education. 